\title{
Correction to: Assessment of wastewater reuse potential for irrigation in rural semi-arid areas: the case study of Punitaqui, Chile
}

\author{
Published online: 27 September 2020 \\ c) Springer-Verlag GmbH Germany, part of Springer Nature 2020

\section{Correction to: \\ Clean Technologies and Environmental Policy \\ (2020) 22:1325-1338 \\ https://doi.org/10.1007/s10098-020-01874-3}

Livia Serrao $^{1} \cdot$ María Molinos-Senante $^{2} \cdot$ Marco Bezzi $^{1} \cdot$ Marco Ragazzi $^{1}$

In the original publication, the given name and the family name of all the authors were swapped. It has been updated in this correction.

Publisher's Note Springer Nature remains neutral with regard to jurisdictional claims in published maps and institutional affiliations.

The original article can be found online at https://doi.org/10.1007/ s10098-020-01874-3.

\section{María Molinos-Senante} mmolinos@uc.cl

1 DICAM, Dipartimento di Ingegneria Civile, Ambientale e Meccanica, Università di Trento, Via Mesiano 77, 38122 Trento, Italy

2 Departamento de Ingeniería Hidráulica y Ambiental, Pontificia Universidad Católica de Chile, Av. Vicuña Mackenna, 4860 Santiago, Chile 